\title{
Correction to: Why ethical audit matters in artificial intelligence?
}

\section{Nitesh Rai ${ }^{1}$ (D)}

Published online: 19 October 2021

(c) Springer Nature Switzerland AG 2021

\section{Correction to: Al and Ethics}

https://doi.org/10.1007/s43681-021-00100-0

The author made a mistake in the original article. The app referred to in Section 2.1 has been corrected to "thisisyourdigitallife".

The original article has been corrected.

The original article can be found online at https://doi.org/10.1007/ s43681-021-00100-0.

\section{Nitesh Rai}

niteshrai226@gmail.com

1 Department of Political Science, University of Delhi, Delhi 110007, India
Publisher's Note Springer Nature remains neutral with regard to jurisdictional claims in published maps and institutional affiliations. 